\title{
ANALISIS PROBLEMATIKA PEMBELAJARAN MATEMATIKA DI SEKOLAH MENENGAH PERTAMA DAN SOLUSI ALTERNATIFNYA
}

\author{
Raras Kartika Sari \\ Pendidikan Matematika, IKIP Budi Utomo Malang \\ raraskartikasari@gmail.com
}

\begin{abstract}
Abstrak
Penelitian ini bertujuan untuk mendeskripsikan problematika dalam pembelajaran matematika dan solusi alternatifnya di Sekolah Menengah Pertama (SMP) Muhammadiyah 8 Batu. Metode yang digunakan dalam penelitian ini adalah pendekatan kualitatif. Subjek penelitian adalah dua peserta didik dari kelas IX-1 dan kelas IX-6 dan dua guru matematika di SMP Muhammadiyah 8 Batu yang mengajar di kelas IX-1 dan IX-6. Instrumen penelitian yang digunakan dalam penelitian ini adalah observasi, angket dan wawancara. Hasil penelitian ini menunjukkan problematika pembelajaran matematika di SMP Muhammadiyah 8 Batu yaitu penguasaan konsep matematika yang tidak baik dan motivasi belajar yang tidak baik. Solusi alternatif dari problematika tersebut adalah scaffolding, pendekatan personal kepada peserta didik, penggunaan media pembelajaran yang lebih menarik motivasi peserta didik dalam belajar matematika, dan penerapan metode pembelajaran yang sesuai dengan karakteristik peserta didik.
\end{abstract}

Kata kunci: problematika, pembelajaran, matematika, solusi

\begin{abstract}
The study was conducted aimed at finding out the problems in learning mathematics in junior high schools, especially at SMP Muhammadiyah 8 Batu with alternative solutions. The method used in this study is a qualitative research approach. The research subjects were two students from class IX-1 and IX-6 each representing students from homogeneous and heterogeneous classes, as well as two math teachers at SMP Muhammadiyah 8 Batu who each taught in homogeneous and heterogeneous classes. Analysis of the data used in this study is analysis of observations, questionnaire results and interview transcripts. Based on the results of the research, it was found that the problem of mathematics learning in SMP Muhammadiyah 8 Batu is 1) poor mathematical mastery; 2) learning motivation that is not good; 3 ) the use of instructional media and 4) the application of learning methods. An alternative solution to these problems is the need for scaffolding when students experience difficulties, there is a personal approach to students, it is necessary to use more interesting learning media, for example macromedia flash and educational games, the application of learning methods tailored to the characteristics of good students for homogeneous and heterogeneous classes.
\end{abstract}

Keywords: problematics, learning, mathematics, solutions 


\section{PENDAHULUAN}

Matematika memiliki peranan penting dalam segala aspek kehidupan terutama dalam meningkatkan daya pikir manusia (Sumatini, 2016, Sahudin, 2014; Damaningsih, 2016). Pembelajaran matematika merupakan suatu proses yang mengandung dua jenis kegiatan yang tidak terpisahkan yaitu belajar dan mengajar. Kedua kegiatan tesebut berpadu menjadi suatu kegiatan yang membuat terjadinya interaksi antara peserta didik dengan guru dan sesama peserta didik disaat berlangsungnya proses belajar disekolah (Sahudin, 2014).

Proses pembelajaran merupakan sesuatu yang penting dalam dunia pendidikan yang patut diperhatikan, direncanakan dan dipersiapkan, karena pembelajaran merupakan penentu utama dalam keberhasilan pendidikan (Hamid, 2013; Damaningsih, 2016). Proses belajar mengajar matematika berhubungan dengan banyak konsep. Konsep matematika memiliki hubungan antara satu konsep dengan konsep lainnya. Peserta didik menganggap bahwa matematika merupakan pelajaran yang sulit, karena sifatnya yang abstrak (Novitasari, 2016).

Pada pembelajaran matematika penguasaan konsep menjadi salah satu problematika yang sering muncul di sekolah menengah pertama (Novitasari, 2016). Konsep matematika yang abstrak tersusun secara berurutan dan berjenjang serta diperlukan pembuktian khusus, sehingga dalam proses pembelajaran konsep matematika sebelumnya harus dikuasai karena merupakan prasyarat untuk melanjutkan konsep berikutnya (Misel, 2016; Suandito, 2017).

Kualitas pembelajaran memerlukan berbagai upaya untuk mewujudkannya. Upaya tersebut terkait dengan berbagai komponen yang terlibat di dalam pembelajaran (Hikmawati, 2013). Pemerintah perlu menghasilkan guru yang berkualitas untuk setiap kelas matematika (Wasserman, 2010). Guru matematika yang baik harus memberikan pengetahuan prasyarat, mempromosikan pemahaman matematika, terlibat dan memotivasi peserta didik, dan membutuhkan manajemen yang efektif (Wasserman, 2010). Jadi guru matematika yang kompeten diperlukan dalam pembelajaran matematika untuk menghasilkan pembelajaran yang berkwalitas.

Hasil belajar matematika masih jauh dari harapan, walaupun usahausaha pemerintah untuk meningkatkan dan memperbaiki prestasi belajar matematika dalam setiap jenjang pendidikan telah banyak dilakukan, antara lain: revisi kurikulum matematika, penataran guru matematika, penyediaan sarana-prasarana pembelajaran, dan sebagainya. Namun kenyataan menunjukkan bahwa hasil belajar matematika masih rendah (Hikmawati, 
2013). Penggunaan metode yang kurang tepat dalam menyampaikan materi dapat membuat proses belajar mengajar cenderung tidak efektif (Agustyaningrum, 2016).

Masalah dalam belajar dapat dibedakan menjadi dua yaitu ketidakmampuan belajar yang terletak dalam perkembangan kognitif peserta didik tersebut dan penyebab kesulitan belajar di luar anak atau masalah lain pada peserta didik (Dumont, 1994; Steenbrugge, et all., 2011; Asnawir \& Usman B, 2002; Hikmawati, 2013). Diagnosis ketidakmampuan belajar dapat ditarik dari penilaian global anak termasuk pembelajaran dan konteks sekolah (Mazzocco \& Myers, 2003; Steenbrugge, dkk., 2001). Diagnosis utama didasarkan pada gabungan penggunaan alat diagnostik (Denburg \& Tranel, 2003; Kamphaus, dkk., 2000; Steenbrugge, et all., 2011).

Banyak peserta didik di semua tingkat pendidikan di negara-negara berkembang memiliki masalah dalam pembelajaran matematika (Mundla, 2012). Masalah yang timbul disebabkan oleh masalah dari dalam dan dari luar diri peserta didik. Masalah akademik dan pribadi peserta didik dalam lembaga pendidikan dapat diidentifikasi dan diselesaikan dalam sejumlah cara yang berhubungan dengan psikolog pendidikan, konselor sekolah, dan penelitian pendidikan. Biasanya, masalah peserta didik cenderung banyak, beragam dan kompleks dan membutuhkan interdisipliner pendekatan untuk memahami mereka secara memadai.

Problematika pembelajaran matematika dapat disebabkan oleh faktor dari peserta didik maupun guru. Salah satu faktor guru yang menimbulkan problematika dalam pembelajaran matematika adalah kurangnya penguasaan metode dan pendekatan pembelajaran yang tepat untuk digunakan dalam setiap kelas yang berbeda.

Berdasarkan latar belakang di atas maka rumusan masalah dalam penelitian ini adalah bagaimana problematika dalam pembelajaran matematika dan solusi alternatifnya di Sekolah Menengah Pertama (SMP) Muhammadiyah 8 Batu. Tujuan penelitian ini yaitu mengetahui problematika dalam pembelajaran matematika dan solusi alternatifnya di Sekolah Menengah Pertama (SMP) Muhammadiyah 8 Batu.

\section{METODE PENELITIAN}

Pendekatan penelitian yang digunakan merupakan pendekatan kualitatif. Penelitian dilaksanakan di SMP Muhammadiyah 8 Batu. Subjek penelitian adalah dua peserta didik dari kelas IX-1 dan IX-6 dan dua orang guru matematika di SMP Muhammadiyah 8 yang mengajar kelas IX-1 dan IX6.

Instrumen yang digunakan dalam penelitian ini berupa lembar observasi, angket peserta didik dan transkrip wawancara. Analisis penelitian 
dilakukan dengan cara menganalisis lembar obsevasi, analisis hasil angket peserta didik dan hasil transkip wawancara . Hasil lembar observasi dan angket dianalisis secara khusus pada problematika pembelajaran matematika kemudian dikombinasikan dengan hasil wawancara.

\section{HASIL DAN PEMBAHASAN}

Berdasarkan hasil observasi, angket, dan wawancara terhadap guru matematika di SMP Muhammadiyah 8 Batu menunjukkan adanya problematika yang terjadi dalam pembelajaran matematika. Berikut uraian mengenai problematika tesebut.

Problematika pertama dalam pembelajaran matematika di SMP Muhammadiyah 8 Batu adalah pemahaman konsep matematika yang kurang matang. Hal ini berdampak pada poses pembelajaran matematika di dalam kelas. Kurangnya konsep matematika peserta didik yang dibawa dari jenjang kelas sebelumnya. Kebanyakan peserta didik cenderung melupakan pokok bahasan yang telah diajarkan di jenjang kelas sebelumnya.

Rendahnya penguasaan konsep matematika peserta didik pada jenjang sebelumnya membuat guru harus selalu mengulang materi dan hal ini akan menghabiskan banyak waktu pelajaran yang terbuang sia-sia serta tidak dapat digunakan untuk menjelaskan materi baru sesuai dengan rencana pelaksanaan pembelajaran yang telah diancang sebelumnya.

Rendahnya penguasaan konsep matematika peserta didik dapat dijabarkan dalam hal-hal sebagai berikut: a)intelegensi peserta didik yang kurang baik, b)bakat yang kurang atau tidak sesuai dengan bahan pelajaran yang diberikan oleh guru, c)aktifitas belajar di dalam kelas yang kurang dan lebih banyak malas daripada melakukan aktifitas belajar, d)kebiasaan belajar yang kurang baik yaitu belajar dengan penguasaan ilmu pengetahuan pada tingkat hafalan dan tidak dengan pengertian yang dapat mereka mengerti tanpa hafalan.

Problematika kedua dalam poses pembelajaran matematika di SMP Muhammadyah 8 Batu adalah rendahnya motivasi peserta didik yang kurang baik akibat dari adanya game online di sekitar lingkungan sekolah. Keberadaan game online di sekitar sekolah mengakibatkan banyak peserta didik yang bebondong-bondong mendatangi tempat tersebut ketika jam istiahat sehingga mereka sering lupa waktu, kemudian telambat memasuki kelas pada jam pelajaran matematika.

Peserta didik sering terlambat memasuki kelas dan tidak semangat mengikuti pelajaran matematika. Hal ini sesuai dengan kutipan wawancara berikut: "Terkadang peserta didik banyak yang membolos dan Saya harus mendatangi dan melakukan sidak di dalam warnet untuk mencari mereka yang sedang asik bemain game". 
Problematika ketiga dalam pembelajaran matematika di SMP Muhammadiyah 8 Batu adalah penggunaan media. Guru tidak selalu menggunakan media pembelajaran dan kurang menggunakan media yang bervariasi. Hal ini dikarenakan tidak semua materi matematika dapat dijelaskan dengan menggunakan media yang konkrit dan media yang digunakan tidak selalu dapat mendukung materi pembelajaran yang diajarkan. Hal ini dapat dilihat dari kutipan wawancara terhadap guru sebagai berikut: "Saya tidak selalu menggunakan media pembelajaran karena menurut saya tidak semua materi matematika dapat menggunakan media konkrit dalam menjelaskannya."

Beberapa peserta didik mengaku senang menggunakan bantuan media pembelajaran namun ada sebagian yang merasa masih bingung dan tidak paham sehingga guru harus mengulang materi dengan ceramah. Hal ini sesuai dengan hasil wawancara beikut: "Saya merasa senang dengan penggunaan media, tapi saya merasa tidak begitu paham dengan materi yang diajarkan dan harus diulang-ulang."

Peserta didik beranggapan bahwa penggunaan media dalam proses pembelajaran matematika justru hanya membuang-buang waktu saja. Hal ini terlihat dari kutipan wawancara berikut: "Saya lebih suka pembelajaran dengan menggunakan ceramah saja bu, karena menurut saya penggunaan media pembelajaran hanya membuang-buang waktu saja".

Problematika keempat dalam pembelajaran matematika pada poses pembelajaran di SMP Muhammadiyah 8 Batu yaitu penggunaan metode pembelajaran yang tidak dapat diterapkan pada semua kelas dengan jenjang yang sama. Hal ini sesuai dengan hasil wawancara berikut: "Setiap semester Saya merancang Rencana Pelaksanaan Pembelajaran (RPP) yang seharusnya dapat Saya gunakan untuk semua kelas dalam jenjang yang sama”.

Guru mempersiapkan satu RPP dalam satu semester untuk dapat diterapkan dalam satu jenjang kelas yang sama, tapi pada kenyataannya RPP yang telah di rancang tidak dapat diterapkan secara serta merta untuk setiap kelas. Hal ini dikarenakan setiap kelas memiliki karakteristik peserta didik yang berbeda-beda. Kelas yang pada dasarnya berisi peserta didik dengan kemampuan menengah ke atas cenderung lebih dapat menerima pelajaran matematika dengan menggunakan RPP yang telah dirancang dengan menggunakan metode pembelajaran yang bervariasi dan media pembelajaran yang telah disediakan. Sedangkan kelas dengan peserta didik berkemampuan sedang ke bawah cenderung tidak dapat mengikuti pelajaran dengan menggunakan RPP yang telah dirancang dengan menggunakan banyak metode pembelajaran yang bevariasi.

Kelas yang berisi peserta didik dengan kemampuan menengah ke atas lebih mudah dikondisikan dengan metode pembelajaran yang bervariasi. 
Sedangkan kelas dengan peserta didik berkemampuan sedang ke bawah, ketika guru menerapkan metode pembelajaran dengan banyak variasi, mereka cenderung kurang dapat mengikuti instruksi dari guru.

Hal ini menjadi salah satu problematika pembelajaran matematika yang dialami oleh guru, dimana peserta didik tidak dapat dikondisikan dengan satu metode pembelajaran secara besamaan dalam jenjang kelas yang sama. Ketidakmerataan penggunaan metode pembelajaran ini mengakibatkan adanya ketidaksamaan dalam tercapainya tujuan pembelajaran pada setiap kelas dengan jenjang yang sama.

Berdasarkan hasil penelitian yang sudah diuraikan di atas, terdapat solusi untuk empat problematika yang ditemukan selama penelitian. Empat problematika dan solusi tersebut dijabarkan sebagai berikut.

Solusi untuk poblematika pertama yaitu pemahaman konsep matematika yang kurang baik, seharusnya guru memberikan lebih banyak scaffolding. Scaffolding bertujuan untuk memberikan bantuan kepada peserta didik saat menemukan kesulitan dalam pembelajaran. Hal ini sesuai dengan pendapat Khatimah (2017) bahwa pemberian scaffolding dapat menangani hambatan berpikir peserta didik dalam memecahkan masalah.

Solusi untuk problematika kedua yaitu motivasi peserta didik yang kurang baik yakni dengan cara guru memberikan pendekatan personal, memberikan bimbingan dan pendekatan psikologis kepada peserta didik agar lebih semangat dalam mengikuti pembelajaran matematika. Seperti yang diungkapkan Podomi (2015) bahwa ada pengaruh yang baik dalam pembelajaran dengan menggunakan pendekatan analogi personal terhadap kemandirian belajar peserta didik.

Solusi untuk problematika ketiga yaitu dengan menggunakan media pembelajaran yang tidak dapat mendukung materi sepenuhnya dilakukan secara kontekstual dan memanfaatkan segala sesuatu yang ada di lingkungan sekolah. Media pembelajaran berfungsi sebagai penyaji stimulus informasi, sikap, juga lain-lain dan untuk meningkatkan keserasian dalam penerimaan informasi. Media juga berfungsi untuk mengatur langkah-langkah kemajuan serta memberikan umpan balik. Hal ini sesuai dengan hasil penelitian (Asnawir, 2002; Toheri dan Aziz, 2016).

Selain itu guru harus pandai memilih media pembelajaran yang cocok dalam menyampaikan materi pelajaran Matematika. Media pembelajaran dapat menggunakan media bebasis digital misalnya dengan menggunakan media pembelajaran macromedia flash dan game edukasi. Macromedia flash dapat dengan mudah memotivasi belajar peserta didik dan merangsang peserta didik untuk aktif dalam proses pembelajaran dan tidak memperkecil arti pokok pembelajarannya, tetapi justru membantu memperjelasnya (Hirtanto, et all., 2015). 
Penggunaan media pembelajaran dapat menstimulus semangat peserta didik dalam belajar. Kondisi ini sesuai dengan pernyataan Hirtanto (2015) yaitu penggunaan media dalam proses pembelajaran merupakan salah satu upaya untuk memotivasi siswa dalam meningkatkan kualitas hasil belajar para siswa.

Solusi untuk penerapan metode pembelajaran harus disesuaikan dengan karakteristik peserta didik. Kelas homogen dapat diterapkan pembelajaran yang bervariasi, dan untuk kelas heterogen juga dapat diterapkan metode pembelajaran yang bervariasi namun memerlukan bimbingan yang lebih banyak saat pembelajaran. Kesesuaian cara yang digunakan dalam pembelajaran dengan materi dan karakteristik peserta didik dapat membuat proses pembelajaran matematika menjadi lebih menyenangkan, sehingga proses belajar mengajar akan menjadi lebih efektif, yang pada akhirnya akan membuat peserta didik memperoleh prestasi belajar yang baik (Agustyaningrum, 2016).

\section{KESIMPULAN DAN SARAN}

Problematika pembelajaran matematika di SMP Muhammadiyah 8 Batu adalah 1)pemahaman konsep matematika yang tidak matang, hal ini mengakibatkan peserta didik tidak memiliki bekal pengetahuan dalam pembelajaran matematika dari jenjang kelas sebelumnya, 2)motivasi belajar yang kurang baik, banyak peserta didik yang memiliki motivasi rendah dalam dalam pembelajaran matematika, 3)penggunaan media pembelajaran belum efektif dalam menarik minat peserta didik untuk belajar, dan 4)penerapan metode pembelajaran belum sesuai dengan karakteristik peserta didik.

Solusi dari problematika yang tejadi di SMP Muhammadiyah 8 Batu menurut hasil penelitian adalah 1) pemberian scafollding, pemberian scafollding diberikan untuk peserta didik yang memiliki problematika tentang penguasaan konsep ilmu yang tidak baik dari jenjang kelas sebelumnya sehingga peserta didik lebih memahami materi yang di ajarkan oleh guru, 2)guru memberikan pendekatan personal, memberikan bimbingan dan pendekatan psikologis kepada peserta didik sehingga peserta didik lebih termotivasi untuk mengikuti proses pembelajaran matematika, 3)penggunaan media kontekstual dan berbasis digital misalnya macromedia flash dan game edukasi untuk menstimulus peserta didik dan adanya penyesuaian media pembelajaran dengan materi yang diajarkan, dan 4)penerapan metode pembelajaran disesuaikan dengan karakteristik peserta didik sesuai kelas homogen maupun heterogen.

Saran yang dapat diungkapkan yaitu sebaiknya guru memperhatikan berbagai macam problematika yang ada di kelas dan mencari solusinya. Jika problematika terkait penguasaan konsep, maka sebaiknya guru dapat 
memberikan scaffolding. Jika problematika terkait motivasi, maka sebaiknya guru memberikan bimbingan dan pendekatan psikologis. Jika problematika terkait media pembelajaran, maka sebaiknya guru menggunakan media yang sesuai dengan materi yang diajarkan. Jika problematika terkait karakteristik peserta didik, maka sebaiknya guru menggunakan metode pembelajaran yang sesuai dengan karakteristik peserta didik di kelas tersebut. Sehingga setiap kelas diberikan perlakukan yang tidak selalu sama karena menyesuaikan kondisi di kelas tersebut.

\section{DAFTAR PUSTAKA}

Agustyaningrum, N. dkk. (2016). Pengaruh Penggunaan Media Pembelajaran Mind Mapping Terhadap Prestasi Belajar Matematika Siswa Kelas VII Smp Tunas Baru Jin-Seung Batam Tahun Ajaran 2014/2015. JurnalPythagoras 5(1): 32-37 ISSN 2085-9996.

Asnawir \& Usman B. (2002). Media Pembelajaran. Jakarta : Ciputat Press.

Damaningsih, E. N. (2016). Dampak Strategi Pembelajaran dan Kemandirian Peserta didik terhadap Hasil Belaja Matematika SMP Materi Himpunan. NaskahPublikasi Ilmiah Universitas Muhammadiyah Surakarta.

Dumont, J. J. (1994). Leerstoornissen. Deel 1: Theorie en Model [learning Disabilities. Part 1: Theory and Model]. Rotterdam: Lemniscaat.

Denburg, N.L. \& Tranel, D. (2003). Acalculia and disturbances of the body schema. In K.M. Heilman \& E. Valenstein (Eds.),Clinical Neuropsychology (4th ed.). (pp. 161-184). New York: Oxford University Press.

Hamid, S. (2011). Metode Edutrainment. Jojakarta: Diva Press.

Hikmawati, dkk. (2013). Pengaruh Penggunaan Media Pembelajaran Dan Gaya Kognitif Terhadap Hasil Belajar Matematika Siswa Kelas VIII Madrasah Tsanawiyah. Tekno-Pedagog.i Vol. 3 No. 2: 1-11, ISSN 2088205X.

Hirtanto, dkk. (2015). Eksperimentasi Pembelajaran Matematika Menggunakan Media Komputer pada Materi Pokok Persamaan Garis Lurus Ditinjau dari Motivasi Belajar Siswa Kelas VIII SMP Surakarta Tahun Ajaran 2011/2012. Jurnal Elektronik Pembelajaran Matematika Vol. 3, No. 8 ISSN 2339-1685.

Kamphaus, R. W., dkk. (2000). Current Trends in Psychological Testing of Children. Professional Psychology: Research and Practice, 31, 155-164.

Khatimah, K., Cholis S., \& Hery S. (2017). Pemberian Scaffolding untuk Mengatasi Hambatan Berpikir Siswa dalam Memecahkan Masalah Aljabar. JKPM: Jurnal Kajian Pembelajaran Matematika, 1(1), 36-45.

Mazzocco M. M., \& Myers G. F. (2003). Complexities in Identifying and Defining Mathematics Learning Disability in the Primary School Age Years. Annals of Dyslexia, 53: 218-253. 
Misel, E. S. (2016). Penerapan Pendekatan Matematika Realistik Untuk Meningkatkan Kemampuan Representasi Matematis Siswa. Didaktik , 10 (2), 27-36.

Mundla, L. (2012). The Assessment of Math Learning Difficulties in a Primary Grade-4 Child with High Support Needs: Mixed Methods Approach. International Electronic Journal of Elementary Education, 4(2), 347-366.

Novitasari, D. (2016). Pengaruh Penggunaan Multimedia Interaktif Terhadap Kemampuan Pemahaman Konsep Matematis Siswa. Jurnal Fibonacci, 2 (2).

Podomi, P.A \& Jailani. (2015). Pengaruh Pendekatan Analogi Personal terhadap Prestasi, Penalaran, dan Kemandirian Siswa Materi Dimensi Dua di SMK. Pythagoras: Jurnal Pendidikan Matematika, 10 (1), 61-70.

Sahudin, A. (2014). Implementasi Strategi Pembelajaran Discoveryuntuk Meningkatkan Kemampuan Pemecahan Masalah Matematis dan Motivasi Belajar Peserta didik SMA. Jurnal Pendidikan Unsika, 2 (1).

Steenbrugge, V. H., dkk. (2011). Mathematics Learning Difficulties in Primary Education: Teachers' Professional Knowledge and the Use of Commercially Available Learning Packages. Publication in Educational Studies.

Suandito, B. (2017). Bukti informal dalam Pembelajaran Matematika. Jurnal Al-Jabar, 8 (1).

Sumatini, T. S. (2016). Peningkatan Kemampuan Pemecahan Masalah Matematis Siswa Melalui Pembelajaran Berbasis Masalah. Jurnal Pendidikan Matematika STKIP GaruT, 8 (3).

Toheri\& Aziz, A. (2016). Pengaruh Penggunaan Media Belajar Audio Visual terhadap Hasil Belajar Siswa Mata Pelajaran Matematika pada Pembahasan Dimensi Tiga. Jurnal Pendidikan Matematika IAIN Syekh Nurjati Cirebon.

Wasserman, N. H. (2010). Inside The Uteach Progam: Implications for Research in Mathematics Teacher Education. Journal of Mathematics Education at Teachers Collage, Spring Summer 2010 Volume 1. 